Journal of Gender Studies

\title{
The identity of 'the other' for sexual violence victims: is there anything new in sexual violence prosecutions before the International Criminal Court?
}

\section{Gozde Turan}

To cite this article: Gozde Turan (2017) The identity of 'the other' for sexual violence victims: is there anything new in sexual violence prosecutions before the International Criminal Court?, Journal of Gender Studies, 26:6, 662-674, DOI: 10.1080/09589236.2016.1155977

To link to this article: https://doi.org/10.1080/09589236.2016.1155977

\section{曲 Published online: 15 Mar 2016.}

\section{Submit your article to this journal $\sqsubset$}

Џ Article views: 388

Q View related articles $\longleftarrow$

View Crossmark data ¿ 


\section{The identity of 'the other' for sexual violence victims: is there anything new in sexual violence prosecutions before the International Criminal Court?}

\section{Gozde Turan}

Faculty of Economics, Administrative and Social Sciences, Department of International Relations, Bilkent University, Ankara, Turkey

\begin{abstract}
Despite the spectacular development in the field of international criminal law, critical feminism stresses the narrow scope of the sex and gender crimes in the Rome Statute establishing the first permanent International Criminal Court. The current international criminal law discourse, as expressed by recent case law, is geared towards the protection of certain groups targeted on account of their distinctiveness within the framework of a conflict situation, and gender is not recognized as one of these group identities. The question whether international criminal law on sexual violence applies only to inter-group conflicts brings to the fore an uneasy likelihood of exclusion of some recently emergent situations where identities of the conflicting parties transcend a particular ethnicity or nationality, and where victims of sexual violence belong to the same group as their perpetrators. The article argues that, rather than the Rome Statute or newly introduced rules and regulations, a significant obstacle in developing gender justice is the narrow interpretation of sexual violence to inter-group hostilities.
\end{abstract}

ARTICLE HISTORY

Received 11 March 2015

Accepted 16 February 2016

\section{KEYWORDS}

Sexual violence; gender crimes; gender justice; international criminal law; International Criminal Court

\section{Introduction}

It is a widespread conviction in the feminist literature that the International Criminal Court (ICC or 'the Court'), which came into effect in 2002 with the purpose of prosecuting the crime of genocide, crimes against humanity, war crimes and the crime of agression (Article 5), reflects a genuine progress not just in terms of the prosecution of the international crimes but also for gender justice (Bedont \& Hall-Martinez, 1999; Boon, 2001; Chappell, 2011, 2014; Charlesworth \& Chinkin, 2000; Copelon, 2000; Lehr-Lehnardt, 2001; Steains, 1999). The idea that the ICC implicates and contributes to gender justice is based primarily on the novelties introduced by the Rome Statute (1998), Elements of Crimes (2002), Rules of Procedure and Evidence (2000), the case law, as well as the provisions on the Court's judicial, prosecutorial and administrative structure.

The problem this article seeks to unfold is the narrow interpretation of the ICC on sexual violence crimes as crimes against humanity and war crimes, which themselves are already narrow and restricted to mass scale atrocities. It is not the case that the ICC is the only place to discuss, define and prosecute gender based crimes, or that such crimes only occur when the ICC says they occur. Many rapes, sexual assaults, forced sterilizations, or enforced pregnancies occur and will continue to occur inside and 
outside of conflict zones which will not be within the remit of the ICC. Jurisdiction of the ICC comes to the agenda only when there arises a common sense that international crimes are committed and not prosecuted by local jurisdiction mechanisms due to the latter's unwillingness or incapacity. In other words, the principle of complementarity, as envisaged in Article 17 of the Statute, rather than prosecuting the crimes of each and every sexual violence crime inside or outside of conflict zones, renders the intervention of the Court possible with regards to sexual violence crimes when local authorities fail to prosecute these crimes that are deemed as amongst the most serious of international concern, and committed as part of the three enumerated international crime categories. Yet, the complementarity principle should not be taken as a straightforward reassurance about the reach of the international criminal law, nor as an outright redressment mechanism where national courts make up what is left unnoticed or ignored by the ICC.

When violence is framed in a limited manner, it is not only the international criminal prosecutions being affected but also the national courts and corresponding legal systems that are prone to be affected to follow such a limited and narrow understanding on sexual violence. International criminal law occupies a complex role evidenced by the interplay between the international and the local. Moreover, international criminal law, while defining and framing modes of violence also determines the modes of resistance to such violence. In other words, international criminal law, like other fields of international law, is in an interactive as well as complementary relationship with national legal systems which concerns not only the timeframe and loci but also the very nature and substance of the law to be applied in a particular legal dispute. The possible implications might be that the national-level prosecutions borrow from the international the narrowed discourse on sexual violence crimes which is unfortunately going to restrain the potential of national proceedings to redress what has been unaddressed before international criminal courts and tribunals.

It is not the aim of this article to deny the undeniable achievement of international criminal law and international criminal courts and tribunals in recognizing the use of rape and other forms of sexual violence as a weapon of war, which many feminist scholars underscore its significance (Baaz \& Stern, 2009; Banwell, 2014; Copelon, 2000; Leatherman, 2007, 2011; MacKinnon, 1994, 2006, 2008; Meger, 2010; Rittner \& Roth, 2012; Stiglmayer, 1994). It is not to suggest that the ICC should enlarge its jurisdiction to cover incidents of sexual assault that occur in situations other than mass scale atrocities either. It is certainly infeasible, at least under current circumstances, for an international criminal court to address every crime category commonly codified in most domestic legal systems without any delimitation on subject matter jurisdiction as well as temporal, territorial and personal jurisdictions. Given the limited scope of the ICC in terms of the crimes within its jurisdiction, the problem in the Court's discursive practice is not that it fails to follow the prosecution of any sexual violence crime whereever and whenever it occurs. What seems to be problematic about the particular interpretation of the ICC on sexual violence crimes is that it constrains sexual violence during mass scale atrocities to acts directed at individuals or groups conceived as the other by at least one of the parties to the conflict.The article purports the view that this restricted and biased discourse is a significant flaw in terms of gender justice which may not be redressed by the national laws in all circumstances since law at local level is in an interactive relationship with the international rather than standing as an isolated body.

To clarify how the ICC frames and represents sexual and gender violence and what is excluded as well as silenced in this framing the study is divided into three sections. The first section will elaborate on the selective and thereby constraining gender discourse in connection with different interpretations of and approaches in the feminist literature. Then, the second section will look at the discursive practices through the recent case law to show that the ICC's approach to sex and gender crimes is conditioned on these crimes being part of a mass scale atrocity whose victims should belong to a different group than that of the perpetrators. The third section sets out the handicap of such conditioning in a dramatically changing world where the concept of human security is under transformation as the need to move beyond the conventional international law discourses arises to respond different conflict situations. Without transcending conventional discourses, the conclusion posits the view that an initiative to revise the Statute to include sex and gender crimes under a separate category is not a feasible option. This is 
not only because the Statute is designed within the framework and limits of a security discourse that takes as its mainstay membership to a community or a group exclusive of sex and gender, but primarily because the main problem is not how the Statute is written but how it is interpreted at the trial stage.

Engaging with discussions on the gender justice that the ICC allegedly represents, it is the main purpose of this article to contribute to the ongoing debate initiated by the critical feminist literature, which contends that the current situation related to sex and gender crimes in international criminal prosecutions is a constraining one rather than an improvement in terms of gender justice. The article also considers the danger of updating conventional discourses through international prosecutions and draws attention to the need of advancing the juridification on sexual violence crimes in order to cover in-group crimes committed during mass scale atrocities.

\section{The ICC: a story of success or an illusion with defects partially revealed?}

Developments in humanitarian law in the twentieth century led to rape and other forms of sexual violence being incorporated into international legal documents albeit within a particular discourse emphasizing the damage caused to the honour and dignity of the victims and their families. Article 27 of the Fourth Geneva Convention (1949) reflects the conventional discourse that a woman subjected to sexual violence would be ashamed by the act stating that women shall be protected against 'any attack on their honour, in particular, rape, enforced prostitution, or any form of sexual assault.' Additional Protocol I to the Geneva Conventions (1977), instead of using the notion of 'honour', stresses that women should 'be the object of special respect.'

Feminist scholarship has criticized the honour discourse of the very first international documents on crimes against women as it, by implication, degrades women to a distinct category of victims who are depicted as weak and vulnerable and who would be ashamed of the sexual assault they are subjected to (Askin, 2003, pp. 299-300; Bedont \& Hall-Martinez, 1999, pp. 70-71; Boon, 2001, p. 627; Hagay-Frey, 2011). This particular discourse on honour has to a certain extent been overcome through developments in international criminal law which carried the prohibition in law to a further stage of criminalization.

The International Military Tribunal for the Far East (Tokyo Tribunal) provided the very initial yet inchoate examples of case law on rape and other sexual violence crimes. The failure of the Tokyo Tribunal to attend to sexual violence crimes the way they deserved was mainly because the attention was directed to the crimes committed in furtherance of an aggressive war, which limited the evidence being gathered to what had happened to the nationals of the Allies (Dolgopol, 2011, pp. 251-258). Although the rape of Chinese women during the Nanjing invasion was prosecuted, large scale and systematic sexual enslavement of women across Asia was overlooked (Henry, 2011). As to the Tokyo Tribunal's counterpart in Europe, the International Military Tribunal (Nuremberg Tribunal) did not cover any gender-related crime in its Charter and prosecutions thus erased all forms of sexual violence during the war in Europe including but not limited to the Holocaust (Ni Aolain, 2000).

The belated judiciary stage for sexual violence crimes has been explained through the particular nature of these crimes, which introduce a plethora of additional difficulties making their prosecution extremely complicated and challenging. Procedural difficulties such as being investigated by males or questions framed for a different purpose (Wood, 2004, p. 305), social and cultural obstacles causing a common unwillingness amongst victims to speak about what they have experienced with a concern of being stigmatized (Beltz, 2008, p. 26) or ostracized (Cahn, 2005, p. 227), even lead to sex and gender crimes being perceived as of 'secondary importance' (Copelon, 2000, p. 234) and at times 'charges of gendered violence are abandoned for easier or more obvious crimes' (Pritchett, 2008, p. 292). ${ }^{1}$

Against this background, the record of the International Criminal Tribunal former Yugoslavia (ICTY), the International Criminal Tribunal for Rwanda (ICTR), and the Special Court for Sierra Leone (SCSL), with regards to sexual violence crimes ${ }^{2}$ is an extremely noteworthy one despite criticism of them reconstructing patriarchal discourses (Hansen, 2000), associating sexual violence with ethnic dimensions of the conflicts (Bedont \& Hall-Martinez, 1999, p. 70; Buss, 2007; Charlesworth, 1999, p. 387; Copelon, 2000; Hagay-Frey, 2011) while obstructing alternative explanations and perspectives (Buss, 2009, 2014). 
The prosecutions in connection with sexual violence before these ad hoc tribunals and courts, rather than being incidental, appear to be the result of the constant and pressing stance of women's rights activists, human rights organizations, academics, and international lawyers including a female judge sitting on the bench. ${ }^{3}$

A similar activism as witnessed for the prosecution of sexual violence crimes before the ad hoc tribunals and courts took place even before the ICC initiated its investigations and prosecutions. Amongst the NGOs, it was most particularly the Women's Caucus for Gender Justice pushing for the term 'gender' and 'gender crimes' to be included in the Statute, and playing an influential role during the Rome Conference (Bedont \& Hall-Martinez, 1999). Notwithstanding these efforts, the narrow and particular interpretation of the term 'gender' itself causes difficulties from a feminist perspective whose goal is to provide a wider, more encompassing and flexible definition. ${ }^{4}$ Charlesworth and Chinkin (2000, pp. 333 and 310) criticize the exclusion of other crimes such as trafficking in women as well as the low number of women in key positions in international criminal tribunals. However, concerns about the number of women in key positions seem not to be valid anymore as the ICC has proved to show an outstanding performance with respect to women judges. Along with the current head prosecutor, Fatou Bensouda, ten out of eighteen judges are women at the moment. ${ }^{5}$ Still, an increase in the number of women representatives do not necessarily result in women-friendly rules. The intersection of numbers and newness is a complicated matter as the very same factors that enhance women's representation in numerical terms such as being 'new' in a field that has been dominated by men might also be those that undermine a substantive representation (Beckwith, 2007, pp. 44-45).

Besides the unprecedented sensitivity on the fair representation of male and female judges as stipulated in Article 36 (8) (a) (iii), 'gender sensitive' prosecution in Article 54 (1) (b), specialized legal counselling for sexual violence victims in Article 36 (8) (b) and more sensitive courtroom procedures in Article 68 are regarded as positive and inspiring moves. The most essential problems appear to be not the number of women in key positions, but the low number of women coming forward to access services provided by the Court, inadequate outreach programs, budget constraints and unsatisfactory implementation on the domestic scale (Chappell, 2011, pp. 175-178). Criticisms and suggestions of this kind give the initial impression that improving the institutional design of the Court and revisions in the Statute would enhance gender justice, while this article purports to underline that the particular international criminal law discourse developed by the case law is a threatening obstacle to reach that goal.

\section{The discursive practices of the ICC case law on sexual violence}

An evaluation of the discursive practices of the ICC requires a closer look into the recent case law in connection with sex and gender crimes. The Rome Statute defines crimes against humanity as any of the acts enumerated under Article 7 (1) committed 'as part of a widespread or systematic attack directed against any civilian population, with knowledge of the attack.' The gender aspect of crimes against humanity reveals itself in Article 7 (1) (g) which reads'rape, sexual slavery, enforced prostitution, forced pregnancy, enforced sterilization, or any other form of sexual violence of comparable gravity' as amongst the acts constituting crimes against humanity. Article 7 (2) (a) of the Statute makes a further clarification of the meaning of an 'attack directed against any civilian population' when it states that it is 'a course of conduct involving the multiple commission of acts referred to in paragraph 1 against any civilian population, pursuant to or in furtherance of a State or organizational policy to commit such attack.'

Similar to the crimes against humanity, war crimes are subject to the jurisdiction of the ICC only when there is a widespread or systematic policy or plan, or when the crimes in question are committed within the framework of a large-scale campaign. The main difference between crimes against humanity and war crimes is the prerequisite for the latter that the criminal act in question should be committed in the course of an armed conflict or as part of a military attack. Though there is no direct reference to a State or organizational policy for war crimes, it is beyond question that the armed conflict in question is one between parties with high level organizational capacity. Different Chambers confirm this approach by underlining, '[t]he hostilities may break out (i) between government authorities and 
organized dissident armed groups or (ii) between such groups' (ICC, 2007, paras. 232-34, 2009, paras. 229-31, 2011a, para. 119).

It is important to underline that crimes against humanity are designed to cover acts committed by the perpetrator against members of his or her own group (Ambos, 2014, p. 63). The war crimes, to the contrary, protects in principle only the legal interest of the other (adversary) party (Ambos, 2014, p. 118). Notwithstanding this significant difference, the ICC case law seems to be on the point of blurring the two categories without representing an expansive reading to cover in-group sexual violence for crimes against humanity. In an attempt to clarify what a 'civilian population' means, the Pre-Trial Chamber II in its decision on the situation in the Central African Republic in the case of The Prosecutor v. Jean-Pierre Bemba Gombo has indicated, '[t]he Chamber concurs with Pre-Trial Chamber I which has stated that the potential civilian victims under article 7 of the Statute could be of any nationality, ethnicity or other distinguishing features' (ICC, 2009, para. 76). Though national or ethnic groups are not counted as constituting the definition of a civilian population exclusively in this decision, the explicit message is that there should be'distinguishing features' to speak of an attack directed against a civilian population that sets the ground for rape and other sexual violence acts as well as other criminal acts under the article.

Against the Court's approach with regards to the 'distinguishing features', what requires further clarification is whether national or ethnic identities of individual victims constitute exclusive features to show that they were part of a particular widespread or systematic attack. In other words, in addition to national or ethnic identities, is it possible to conceive of a case of a crime against humanity or war crime when a state or organized group carries out a systemic or widespread attack against women as women? Hypothetically, it is possible as there is nothing in the Statute or Elements of the Crimes preventing a case to be established in those terms. Yet, recent case law of the ICC proceeds on a dangerous ground indicating in its decisions that otherness may refer to a different national or ethnic group while men or women are taken as representatives of such identities. It appears to be, by the uneasy implication, that when sexual violence is not directed at members of the other group, the Court will dismiss charges of crimes against humanity as well as war crimes.

The ICC Pre-Trial Chamber III, in its Cote d'Ivoire decision (ICC, 2011a, para. 72), holds that'the available information substantiates the Prosecutor's submission', and confirms that victims of rape belonged to a different group and were targeted because of their ethnicity and political affiliation:

[D] uring the period of post-election violence, pro-Gbagbo forces were responsible for acts of rape against individuals who were active and public members of Alassane Ouattara's political party or who, on account of their ethnicity, were considered to be pro-Ouattara (e.g. those who spoke Dioula or Mossi, or who came from Mali). (ICC, 2011a, para. 69)

With regard to the war crimes allegedly committed in Cote d'Ivoire, the same Chamber is of the view that victims were 'individuals who were considered supporters of Alassane Ouattara by pro-Gbagbo forces' (ICC, 2011a, para. 146). ${ }^{6}$ The Chamber connects the incidents of rape committed by pro-Ouattara forces to the ethnic character of the victims stating that 'during their military offensive in the west of Cote d'Ivoire, the FRCI [Force Republicaines de Cote d'Ivoire] raped at least 23 people, all of Guere ethnicity' (ICC, 2011b, para. 166). ${ }^{7}$

Authorizing the Prosecutor for an investigation into the situation in Kenya, Pre-Trial Chamber II (ICC, 2010, para. 155) compares opportunistic rapes and sexual violence with those organized and committed by police and security agents. The latter, the Court indicates, have an ethnic dimension, thus falls within the ambit of its jurisdiction:

While the supporting material corroborates that some of the rapes and sexual violence may be qualified as opportunistic acts facilitated by the general climate of civil unrest and lawlessness, there are however instances of sexual violence encompassing an ethnic dimension and targeting specific ethnic groups. (ICC, 2010, para. 155)

Though the target group in the situation of Kenya has primarily been defined as a 'civilian population supporting the Orange Democratic Movement political party', the Chamber emphasizes the ethnic dimension rather than the political divisions. Statements about 'a Luo victim from Nakuru who was gang raped in January 2008 [whose assailants] were of Kikuyu ethnicity' (ICC, 2012a, para. 258), or a woman 'having been raped in Naivasha by five men who spoke Kikuyu' (ICC, 2012a, para. 259) support 
the argument that the conflict takes place between Kikuyu, who are organized under the Mungiki organization, and non-Kikuyu groups, who are mainly of Luo and Kalenjin origins.

In a more recent decision on the 'Situation in the Democratic Republic of the Congo' (ICC, 2014, para. 36), Pre-Trial Chamber II concludes that the Union des Patriotes Congolais/Forces Patriotiques pour la Libération du Congo (the 'UPC/FPLC') adopted an organisational policy to attack part of the civilian population, belonging to ethnic groups other than the Hema (the 'non-Hema') including rape (counts 4 and 5) and sexual slavery (counts 7 and 8). The Chamber notes:

[T] he alleged multi-ethnic composition of the UPC/FPLC, including the fact that some of its members belonged to ethnic groups that were the object of the attack, cannot in and of itself rule out the fact that the organisation conceived a policy to attack those perceived to belong to ethnic groups other than Hema. (ICC, 2014, para. 20)

In brief, Pre-Trial Chamber II considers that'the non-Hema civilian population to be targeted was selected primarily on the basis of ethnic origin, such as the Lendu, Bira and Nande ethnic groups' (ICC, 2014, para. 19), and not on the basis of political affiliations which overlap with different ethnic identities. Despite the criticism against the Court due to its failure of not including sexual violence within the group and not resorting to Regulation 55 to amend the charges a posteriori (Merope, 2011), it was not possible for the ICC to prosecute and convict Thomas Lubanga Dyilo of charges of sexual slavery of children conscripted into FPLC at the end. The Court, in its judgement (ICC, 2012b, para. 629) and sentencing decision (ICC, 2012c, para. 60), expressed its discontent about the failure of the Prosecution to include sexual violence charges in the indictment. Yet, it was not only the Prosecution, but also the related Chamber which has disregarded sexual slavery of child soldiers under the age of 15 years and has taken it as an activity unrelated to hostilities rather than one which is combat related (ICC, 2007, paras. 261-262). The direct consequence of this interpretation is that sexual violence, sexual slavery and forced impregnation are neglected despite the evidence that girls were'often used to prepare food and to provide sexual services for the commanders' (ICC, 2012b, para. 894).

Nevertheless, some legal scholars confirm the approach of the Prosecution not to include sexual violence charges against girl soldiers arguing that using children under the age of fifteen to participate actively in hostilities cannot include sexual use of these children (Ambos, 2012; Jørgensen, 2012; Tan, 2012). The argument is supported by a further concern that if girl soldiers are taken as active participants of an armed conflict, their status change from 'civilian' to 'soldier' and lose the legal protection otherwise available in International Humanitarian Law which seeks to protect civilians from attacks by belligerents as reflected in the Article 8(2)(b)(i) and (e)(i) of the Rome Statute (Tan, 2012, p 141). It is a perfect example of putting sexual violence at the second place for a girl soldier and establishing a classification of harms on behalf of the victims. In this way, 'certain kinds of bodily harms are elevated over others in terms of their perceived seriousness' (Ni Aolain, 2009, p. 1061).

Pre-Trial Chamber II, in the case of Ntaganda, disagrees with the view that girl soldiers lose legal protection against attack merely by joining to an armed group (ICC, 2014, para. 78), but concludes that they lose the protection afforded by International Humanitarian Law only during their active/direct participation (ICC, 2014, para. 79). This conclusion is directly related to the charges of sexual violence as the Court is of the view that a person cannot take active part in hostilities exactly when (s)he is subjected to sexual violence by members of the same group (ICC, 2014, paras. 79, 80). In brief, the approach represented by different ICC Chambers in the situation of Congo brings to the fore a crucial question regarding what would happen if sexual violence crimes are committed on a systematic and widespread basis, yet within one of the groups that is a party to the conflict. The Lubanga trials disregard the sexual violence of girl soldiers by their perpetrators who belong to the same group while the Ntaganda trials introduce a narrow interpretation of the protection, arguing that sexual violence cannot be taken as a combat-related act within the group.

The requirement that acts have to be directed to a different group cannot be presumed merely because the Court establishes victims with different ethnic or national identities. It might be that the Court resorts to identifying the ethnicity of the victims to demonstrate the systematic, widespread or organizational nature of the conflict, and to distance itself from opportunistic, random or incidental 
acts. Significantly, however, rather than establishing ethnic, national or racial identities as examples of distinguishing features of a civilian or non-combatant population, the Court decisions seem to frame and limit these features with a failure to notice sexual violence within such groups.

The prosecutions before international courts and tribunals are contingent on an intuitive and inductive judicial method (Bassiouni, 2012, p. 286) rather than representing a mere practice of written rules. Prosecution of sexual violence crimes should follow a similar pattern as the'evolutionary developments of the law of mens rea' (Badar, 2006a, p. 346) or the'joint criminal enterprise' (Badar, 2006b) overcoming the 'silence of legislation' (Schabas, 2006, p. 293). However, the dynamic nature of case law reflects thus far the trend to make the prosecution of such violence conditional on particular identities, and leaves alternative interpretations such as the dissenting opinion of Judge Odio-Benito regarding girl child soldiers in the Lubanga case (ICC, 2012d) marginalized. The Court, in so doing, not only describes and depicts what has happened during mass scale atrocities, but also constructs its own borders between groups, and thereby excludes sexual violence within groups. Thus, when the conflict is framed in a certain way, crimes of sexual violence remains largely unprosecuted if not unnoticed on the ground that the acts are not directly linked to the conflict even if the sexual violence takes place in the same context.

\section{Sexual and gender violence within the group: not a threat for the international community}

Though criminal responsibility is individual in international criminal law just as in almost all legal systems, protection seems to cover individuals only with a certain identity before international criminal tribunals. What constitutes the group identity could find answers in an infinite spectrum but the discourse of the ICC delimits such infiniteness through defining what should be understood by the notion of the other. Even though what might be the other is not defined exclusively for crimes against humanity and war crimes, the recent case law provides the uneasy implication that the other cannot be merely 'another woman' or 'another man'. The ICC case law in-progress implies that in order to talk about rape, sexual slavery, enforced prostitution, forced pregnancy, enforced sterilization or any other crime with a gender dimension, the victim should be perceived and targeted by the perpetrator of the crime due to a distinctive feature. Such an approach entails the prosecution of rape and other forms of sexual violence as crimes against humanity or war crimes when men or women are raped or become subject to sexual violence not only as men or women, but first and foremost of all, as members of a 'different group'. As a result, the international prosecutions add on to the construction of false binaries such as the public/private binary for rape which 'in peacetime [...] has too often served to distract attention away from ongoing structural issues that inhibit women's access to justice and legal equality', and likewise 'the war/peace dichotomy has too often placed the focus in the wrong place: on women as representative of something else (family, community, nation) rather than right-holders in and of themselves' (Grewal, 2010, p. 77).

The focus on groups in international criminal law relates to the conviction that it can only be communal activities posing the type of threat that requires global measures and, then, prosecutions when these measures do not work. The relationship between the individual and the State is replaced by a scaled up relationship between communities and the international community at the international level. It is not any more individuals that global governance with a particular security discourse observes, regulates and supervises. It is not any organized crime that is taken into account either, because many cases of organized crime still fall under the jurisdiction of nation-states. It is the ICC filling the gap of the judicial process at the international level when States or organizations with the capacity to challenge state power commit the type of organized crimes defined as international crimes.

For each crime category, only one single act of a perpetrator can meet the criteria set forth for the elements of conduct and consequences. Yet, it does not nullify the fact that these crimes are designed to protect individuals, albeit with a communitarian perspective, and require substantial proof of contextual elements. ${ }^{8}$ For crimes against humanity, the contextual elements refer not only to the punishable acts committed as part of a widespread or systematic attack against a civilian population, but also to 
their 'multiple commissions' (Article 7 (2) (a)). Elements of Crimes of the International Criminal Court also underlines that each and every criminal act should form part of a widespread or systematic attack for crimes against humanity, and the conduct for war crimes should take place in the context of and is associated with an international or non-international armed conflict (see Meron, 2000).

While the ICC discourse seems to be developing towards a human security oriented one, the parameters of what constitutes human security remains highly limited and restricted. ${ }^{9}$ The type of security which should be established for the population does not go beyond actual physical survival though a number of alternatives such as preventing civilian unrest due to famine, providing a context for sustainable development or creating a viable programme to eliminate illiteracy (Acharya, 2001) may well be integrated into this human security oriented discourse. Besides, what is meant by physical survival of communities remains almost the same with the traditional concept of security. Though the state as the referent object of security has been replaced by human groups in this new discourse, what is understood by human security continues to imply mostly the threat of physical violence at a large scale. What is even more striking is the trend to take physical violence between groups whose main motive is to subvert or replace a nation-state as the focus of international criminal law. Even though the aim of a transnational organization might be that of establishing true political control over a given territory, e.g. Islamic State of Iraq and ash-Sham (ISIS), ${ }^{10}$ it remains uncertain how the ICC would respond to the type of violence such transnational organizations direct to their victims especially with regards to sexual violence when the fighting is not characterized with a prospect of establishing a nation-state. In a hard case like ISIS, it might be that the perpetrators select and attack their victims not because they belong to a different ethnic, national, racial or religious group, or they do not share the same political affiliations, but because they are women who should be treated in a certain way in accordance to the ideology of the organization, not as a war strategy or method to cause attrition on the enemy. There is room to cover such violence under the definition of the crime of persecution as a crime against humanity, yet the Court's disappointing approach in the Congo case gives little if any hope for potential situations in the future as well as some actual ones.

Violence against sex and gender groups might remain out of the scope of investigations and prosecutions if the defining features of a civilian population continue to depend on conventional nation-state centric perspectives. Just as it is not the aim of this article to indicate that international prosecutions is a futile initiative, so the aim is not to argue that the ICC should be condemned in its narrowing of international crime categories to mass scale atrocities and dealing with sex and gender crimes in relation to such atrocities. Gender and sex crimes before an international criminal tribunal can hardly encompass situations which are not related to conflict situations and which do not meet the criteria of being widespread, systematic, and repetitive. Yet, it is perilous to limit gender and sexual violence taking place during such conflicts to inter-group criminal activities when groups are taken with reference to other 'ethnic, national or racial' identities. It remains utmost compromised to interpret law applicable to conflict situations through conventional lenses, partially because it might result in disregarding in-group violence, but also because it might fail to respond appropriately to situations of transnational conflicts where parties do not claim a cause on ethnic or national grounds.

If international criminal law proceeds to interpret conflicts through conventional lenses that apply to a substantial number of situations, it will, nonetheless, fall short of handling conflicts between non-state actors who pursue goals transcending not only the national but also the international. Put it differently, the narrow interpretation represented by the ICC implicitly subordinates gender identities to certain other identities that prevents sexual violence committed during mass scale atrocities within certain groups from prosecution, and which cannot be overcome unless case law proceeds in advancing this particular interpretation.

\section{Conclusion: a stalemate rather than progress for gender justice}

The establishment of the ICC has been saluted with the inclusion of sex and gender crimes in the Statute and the introduction of new procedures while it has also become subject to criticisms. Contemporary 
debates over the gender justice the ICC represents and achieves focus on proposals of incorporating additional crime categories to the Statute (Charlesworth \& Chinkin, 2000; Hagay-Frey, 2011), redesigning regulations or rules, increasing the number of female judges and prosecutors (Charlesworth \& Chinkin, 2000), improving the structure of investigative teams (Luping, 2009, pp. 493-495), or empowering the Court against domestic authorities (Chappell, 2011, pp. 175-178). Put differently, critical feminist approaches look at what is missing in the current framework in order to suggest reforms towards achieving true or complete gender justice. Yet, law stands as a reflection of the social world inasmuch as it is a form and source of influence and change. International criminal law is also bound by structural constraints though it has the potential of offering changes to some extent. In this respect, introducing a distinct category for sex and gender crimes in the Statute (Hagay-Frey, 2011, pp. 138-157) does not seem to be a feasible and manageable option, as the post-honour discourse has its own limits and presents a great challenge for sex and gender crimes to be recognized as a distinct crime category.

That rape and other forms of sexual violence are not regarded as an assault or humiliation to a woman's dignity and honour, but are codified as 'criminal acts' under international crimes categories, does not represent the radical change despite the conventional belief that it does so. The ICTR and ICTY prosecutions are considered to represent the renunciation of the once accepted nexus between the patriarchal discourse dominant in the broader social context and the legal discourse in the criminal legal system. Sex and gender crimes are handled interwoven with the ethnic dimensions of the conflicts, and charges of rape are incorporated into the indictments only when there is a nexus between the offence and the widespread and systematic attack (Bedont \& Hall-Martinez, 1999, p. 70; Buss, 2007; Charlesworth, 1999, p. 387).

Gender was not silenced in a particular era as argued by Hagay-Frey (2011), but is continuously being silenced in the name of protection through 'honour', 'dignity,' 'humanity', and now 'membership to a particular community' which mostly refers to an ethnic or national group. The men and women as holding different sexual identities are excluded from representation through 'a too often invisible operation of the homogenizing logic of identity' (Lacey \& Zedner, 1995, p. 314). Thus, the legal entrenchment of rights in the form of group rights, rather than representing the inclusiveness of legal categories, enhances the fixed and restricted boundaries while excluding and silencing alternative and subjugated voices (Lacey \& Zedner, 1995; Unger, 2015).

Given the limited scope of international criminal law with regard to mass scale atrocities, the ICC cannot be objected and condemned because of not investigating and prosecuting individual or non-conflict situations of sexual violence cases. The ICC targets to prosecute mass scale atrocities which are deemed to pose a threat to international peace and security, and in order to achieve this goal, it codifies international crimes with a particular discourse which limits and constrains prosecutions to systematic or widespread conflict situations. Nevertheless, the ICC can and should be criticized if it fails to notice and prosecute such violence that is part of mass scale atrocities even when committed within, not between, conflicting parties. Despite the dynamic dimension of prosecutions, the recent case law that frames and constrains prosecution of sexual violence during mass scale atrocities inspires little hope, if any, concerning the sexual violence crimes within the group. With the exclusion of sexual violence acts which had a widespread and repetitive nature, yet committed by members of the same group, and interpreting them as non-combat related acts, the implication that these acts are expected to target the other is affirmed. If the ICC does not initiate an investigation on a hard case related to crimes committed by transnational organizations like ISIS or Boko Haram, the current international criminal law discourse on sexual violence will continue to be detained within the borders of conventional international law discourses taking the state at its center. As it is, the ICC case law introduces little prospect of prosecuting sexual violence in cases where such violence is directed to victims, not as a war tactic or strategy against a different ethnic or national group, but as part of a particular world view, ideology or understanding on what women should do and how they should be behaved.

Male or female bodies, instead of representing autonomous or sovereign bodies, are taken as depository of group or collective identities where gender is subordinated to these 'other' identities. It may well be that supporting the conservative and restricting discourse of the ICC on account of a true or 
truer gender justice poses even a greater risk than the discourse itself. To establish further advance in gender justice, if not a 'true' or 'complete' one, struggle should be continuous transcending current institutional forms while seeking for alternative and broader interpretations. Feminist scholarship, rather than engaging in revisions and reforms within the framework of the current discourse that might end up with an undesired collaboration in sustaining conventional discourses that are not genuinely revolutionary, should hold a constant critical stance being aware of the inevitability of limits in any justice project. In this respect, the first and foremost question should be who the other is for sexual violence victims. The other for any victim in the context of a conflict is the perpetrator of the sexual violence act regardless of the group identity whether this identity is represented on ethnic, national, religious, political or any other grounds.

\section{Notes}

1. For an argument against the view that sex and gender crimes are hard cases to prove, see MacKinnon (2008).

2. Some of the landmark cases including charges on rape and other forms of sexual violence as crimes against humanity, war crimes and genocide before the ICTR and ICTY are: Prosecutor v. Kunarac et al. (2001), IT-96-23-T \& IT-96-23/1-T (the first case before the ICTY to cover the systematic use of rape and other forms of sexual assault in Foca); Prosecutor v. Mucic et al. (also known as the Celebici trial) (1998), Prosecutor v. Sainovic et al. (2009), Prosecutor v. Brdanin (2004), Prosecutor v. Furundzija (1998), Prosecutor v. Stakic (2003), Prosecutor v. Tadic (1997), Prosecutor v. Jean Paul Akayesu (1998), Prosecutor v. Musema (2000).

3. Judge Pillay of South Africa, who had expertise on gender-related crimes as well as international human rights law, was one of the determinant factors affecting the course of the Akayesu trials (Askin, 2003, p. 318).

4. Oosterveld $(2005,2014)$ disagrees with the view that the term 'gender' is narrowly defined in the Rome Statute, and argues that the Statute presents rather a 'constructive ambiguity' that enables strategic and sustainable intervention for feminists. Though I agree that the ICC, following the ad hoc tribunals' judgments, would develop its interpretation on a case-by-case basis and intend to understand what 'maleness' and 'femaleness' mean in a given context, it seems not very realistic to expect the Court to advance the definition beyond heterosexuality given the emphasize in the Statute (Article 7 (3) ) that 'gender refers to two sexes, male and female, within the context of society'. On the other hand, Steains (1999, 374), Bedont and Hall-Martinez (1999, 203), and Copelon $(2000,237)$ are of the view that the wording in the final part of Article 7 (3), 'within the context of society', would give a certain degree of flexibility to the Court to interpret gender.

5. Available from: http://www.icc-cpi.int/en_menus/icc/structure\%20of $\% 20$ the $\% 20$ court/chambers/Pages/chambers. aspx [Accessed 11 March 2015].

6. Pre-Trial Chamber III refers to information collected by Human Rights Watch (2011, pp. 167-168); and Human Rights Watch (2011, pp. 157-158).

7. Pre-Trial Chamber III, for the incidents of rape mentioned at para. 166, refers to documents such as Human Rights Watch (2011); Amnesty International, 2011.

8. The contextual elements of international crimes should not be confused with elements of conduct and consequences.

9. UNDP, Human Development Report (1994) is the primary formal document signifying an important change on security discourse. Though having considerable differences on the security concept, Christie (2010), Hampson (2008), Martin and Owen (2013), Newman (2010), and Pasha (2013) might be counted as examples for the ongoing debate in the literature.

10. ISIS represents a dramatic shift of strategy in comparison to Al Qaeda despite common certain ideological backgrounds. While ISIS resorts to violence like AI Qaeda as a means of achieving the goal of ensuring the practice of a particular understanding of an Islamic world view, the latter has not declared the control of a given territory as one of its main purposes. See, Al-Tamimi (2014), Zelin (2014).

\section{Acknowledgement}

I would like to thank Dr Tore Fougner and Dr Ali Bilgic for their contributions and support.

\section{Disclosure statement}

No potential conflict of interest was reported by the author. 


\section{Funding}

This research received no specific grant from any funding agency in the public, commercial, or not-for-profit sectors.

\section{Notes on contributor}

Gozde Turan has a PhD from Bilkent University, Department of International Relations. Her research interests include international criminal law, criminal tribunals, gender studies and critical theory.

\section{References}

Acharya, A. (2001). Human security: East versus west. International Journal, 56, 442-460.

Additional Protocol I to the Geneva conventions of 12 August 1949, and relating to the protection of victims of international armed conflicts. (1977, June 8). 1125 U.N.T.S. 3.

Al-Tamimi, A. J. (2014). The dawn of the Islamic State of Iraq and ash-Sham. Middle East Forum, 27, 5-15.

Ambos, K. (2012). The first judgment of the International Criminal Court (Prosecutor v. Lubanga): A comprehensive analysis of the legal issues. International Criminal Law Review, 12, 115-153.

Ambos, K. (2014). Treatise on international criminal law: The crimes and sentencing (Vol. II). Oxford: Oxford University Press.

Amnesty International. 'They looked at his identity card and shot him dead' six months of post-electoral violence in Côte d'Ivoire, May 2011, AFR 31/002/2011: CIV-OTP-0002-0647.

Askin, K. D. (2003). Prosecuting wartime rape and other gender-related crimes under international law: Extraordinary advances, enduring obstacles. Berkeley Journal of International Law, 21, 288-349.

Baaz, M.E., \& Stern, M. (2009). Why do soldiers rape? Masculinity, violence, and sexuality in the armed forces in the Congo (DRC). International Studies Quarterly, 53, 495-518.

Badar, M. E. (2006a). Drawing the boundaries of mens rea in the jurisprudence of the International Criminal Tribunal for the former Yugoslavia. International Criminal Law Review, 6, 313-348.

Badar, M. E. (2006b). 'Just convict everyone!' - Joint perpetration: From Tadic to Stakic and back again. International Criminal Law Review, 6, 293-302.

Banwell, S. (2014). Rape and sexual violence in the Democratic Republic of Congo: A case study of gender-based violence. Journal of Gender Studies, 23, 45-58.

Bassiouni, M. C. (2012). Introduction to international criminal law. Leiden: Martinus Nijhoff.

Beckwith, K. (2007). Numbers and newness: The descriptive and substantive representation of women. Canadian Journal of Political Science, 40, 27-49.

Bedont, B., \& Hall-Martinez, K. (1999). Ending impunity for gender crimes under the International Criminal Court. Brown Journal of World Affairs, 6, 65-85.

Beltz, A. (2008). Prosecuting rape in international criminal tribunals: The need to balance victim's rights with the due process rights of the accused. St. John's Journal of Legal Commentary, 23, 167-209.

Boon, K. (2001). Rape and forced pregnancy under the ICC statute: Human dignity, autonomy, and consent. Columbia Human Rights Law Review, 32, 625-675.

Buss, D. E. (2007). Curious visibility of wartime rape: Gender and ethnicity in international criminal law. The Windsor Yearbook of Access to Justice, 25, 3-22.

Buss, D. E. (2009). Rethinking 'rape as a weapon of war'. Feminist Legal Studies, 17, 145-163.

Buss, D. E. (2014). Knowing women translating patriarchy in international criminal law. Social \& Legal Studies, $23,73-92$.

Cahn, N. (2005). Beyond retribution and impunity: Responding to war crimes of sexual violence. Stanford Journal of Civil Rights and Civil Liberties, 1, 217-270.

Chappell, L. (2011). Nested newness and institutional innovation: Expanding gender justice in the International Criminal Court. In M. L. Krook \& F. Mackay (Eds.), Gender, politics and institutions: Towards a feminist institutionalism (pp. 163-180). Palgrave: Macmillan.

Chappell, L. (2014). Conflicting institutions and the search for gender justice at the International Criminal Court. Political Research Quarterly, 67, 183-196.

Charlesworth, H. (1999). Feminist methods in international law. American Journal of International Law, 93, 379-394.

Charlesworth, H., \& Chinkin, C. M. (2000). The boundaries of international law: A feminist analysis. Manchester, $\mathrm{NH}$ : Manchester University Press.

Christie, R. (2010). Critical voices and human security: To endure, to engage or to critique? Security Dialogue, 41, 169-190.

Copelon, R. (2000). Gender crimes as war crimes: Integrating crimes against women into international criminal law. McGill Law Journal, 46, 217-240.

Dolgopol, U. (2011). Knowledge and responsibility: The ongoing consequences of failing to give sufficient attention to the crimes against the comfort women in the Tokyo trial. In Y. Tanaka, T. McCormack, \& G. Simpson (Eds.), Beyond victor's justice? The Tokyo war crimes trial revisited (pp. 243-261). Leiden: Martinus Nijhoff. 
Elements of Crimes of the International Criminal Court. (2002, September 9). ICC-ASP/1/3 at 108, U.N. Doc. PCNICC/2000/1/ Add.2 (2000).

Fourth Geneva Convention relative to the protection of civilian persons in time of war. (1949, August 12). 75 U.N.T.S. 287.

Grewal, K. (2010). Rape in conflict, rape in peace: Questioning the revolutionary potential of international criminal justice for women's human rights. Australian Feminist Law Journal, 33, 57-79.

Hagay-Frey, A. (2011). Sex and gender crimes in the new international law: Past, present, future. Leiden: Martinus Nijhoff.

Hampson, F. O. (2008). Human security. In P. D. Williams (Ed.), Security studies: An introduction (pp. 229-243). New York, NY: Routledge.

Hansen, L. (2000). Gender, nation, rape: Bosnia and the construction of security. International Feminist Journal of Politics, 3, 55-75.

Henry, N. (2011). Silence as collective memory: Sexual violence and the Tokyo trial. In Y.Tanaka, T. McCormack, \& G. Simpson (Eds.), Beyond victor's justice? The Tokyo war crimes trial revisited (pp. 263-282). Leiden: Martinus Nijhoff.

Human Rights Watch, Cote d'Ivoire: crimes against humanity by Gbagbo forces. (2011, March 15). ICC-02/11-3-Anx4.

Human Rights Watch, Cote d'Ivoire: Ouattara forces kill, rape civilians during offensive. (2011, April 9). ICC-02/11-3-Anx4.

ICC. (2007, January 29). Decision on the confirmation of charges, situation in the Democratic Republic of Congo in the case of the Prosecutor v. Thomas Lubanga Dyilo, ICC-01/04-01/06.

ICC. (2009, June 15). Decision on the situation in the Central African Republic in the case of the Prosecutor v. Jean-Pierre Bemba Gombo, ICC-01/05-01/08-424.

ICC. (2010, March 31). Decision pursuant to article 15 of the Rome Statute on the authorization of an investigation into the situation in the Republic of Kenya, ICC-01/09-19.

ICC. (2011a, October 3). Decision pursuant to article 15 of the Rome Statute on the authorization of an investigation into the situation in the Republic of Cote d'Ivoire, ICC-02/11-14.

ICC. (2011b, June 23). Request for authorization of an investigation pursuant to article 15, situation in the Republic of Cote d'Ivoire, ICC-02/11-3.

ICC. (2012a, January 23). Decision on the confirmation of charges pursuant to article 61(7) (a) and (b) of the Rome Statute, situation in the republic of Kenya in the case of the Prosecutor v. Francis Kirimi Muthaura, Uhuru Muigai Kenyatta and Mohammed Hussein Ali, ICC-01/09-02/11.

ICC. (2012b, March 14). Judgment pursuant to article 74 of the Statute, situation in the Democratic Republic of the Congo in the case of the Prosecutor v. Thomas Lubanga Dyilo, ICC-01/04-01/06.

ICC. (2012c, July 10). Decision on sentence pursuant to article 76 of the Statute, situation in the Democratic Republic of the Congo in the case of the Prosecutor v. Thomas Lubanga Dyilo, ICC-01/04-01/06.

ICC. (2012d, July 10). Decision on sentence pursuant to article 76 of the Statute, situation in the Democratic Republic of the Congo in the case of the Prosecutor v. Thomas Lubanga Dyilo, ICC-01/04-01/06 (Judge Odio Benito, dissenting opinion).

ICC. (2014, June 9). Decision pursuant to article 61(7) (a) and (b) of the Rome Statute on the charges of the Prosecutor against Bosco Ntaganda, ICC-01/04-02/06.

Jørgensen, N. H. (2012). Child soldiers and the parameters of international criminal law. Chinese Journal of International Law, 11, 657-688.

Lacey, N., \& Zedner, L. (1995). Discourses of community in criminal justice. Journal of Law and Society, 22, 301-325.

Leatherman, J. (2007). Sexual violence and armed conflict: Complex dynamics of re-victimization. International Journal of Peace Studies, 12, 53-71.

Leatherman, J. (2011). Sexual violence and armed conflict. Cambridge: Polity.

Lehr-Lehnardt, R. (2001). One small step for women: Female-friendly provisions in the Rome Statute of the International Criminal Court. Brigham Young University Journal of Public Law, 16, 317-354.

Luping, D. (2009). Investigation and prosecution of sexual and gender-based crimes before the International Criminal Court. American University Journal of Gender, Social Policy \& Law, 17, 431-496.

MacKinnon, C. A. (1994). Rape, genocide, and women's human rights. Harvard Women's Law Journal, 17, 5-16.

MacKinnon, C. A. (2006). Women's September 11th: Rethinking the international law of conflict. Harvard International Law Journal, 47, 1-31.

MacKinnon, C. A. (2008). The ICTR's legacy on sexual violence. New England Journal of International and Comparative Law, 14, 211-309.

Martin, M., \& Owen, T. (2013). Routledge handbook of human security. New York, NY: Routledge.

Meger, S. (2010). Rape of the Congo: Understanding sexual violence in the conflict in the Democratic Republic of Congo. Journal of Contemporary African Studies, 28, 119-135.

Meron, T. (2000). The humanization of humanitarian law. American Journal of International Law, 94, 239-278.

Merope, S. (2011). Re-characterizing the Lubanga Case: Regulation 55 and the consequences for gender justice at the ICC. Criminal Law Forum, 22, 311-346.

Newman, E. (2010). Critical human security studies. Review of International Studies, 36, 77-94.

Ni Aolain, F. (2000). Sex-based violence and the Holocaust: A reevaluation of harms and rights in international law. Yale Journal of Law \& Feminism, 12, 43-84.

Ni Aolain, F. (2009). Women, security, and the patriarchy of internationalized transitional justice. Human Rights Quarterly, 31, 1055-1085. 
Oosterveld, V. (2005). Definition of gender in the Rome Statute of the International Criminal Court: A step forward or back for international criminal justice. The Harvard Human Rights Journal, 18, 55-84.

Oosterveld, V. (2014). Constructive ambiguity and the meaning of 'gender'for the International Criminal Court. International Feminist Journal of Politics, 16, 563-580.

Pasha, M. K. (2013). Globalization, difference, and human security. New York, NY: Routledge.

Pritchett, S. M. (2008). Entrenched hegemony, efficient procedure, or selected justice: An inquiry into charges for genderbased violence at the International Criminal Court. Transnational Law and Contemporary Problems, 17, $265-305$.

Prosecutor v. Brdanin. (2004, September 1). International Criminal Tribunal for the Former Yugoslavia, IT-99-36-T.

Prosecutor v. Furundzija. (1998, December 10). International Criminal Tribunal for the Former Yugoslavia, IT-95-17/1-T.

Prosecutor v. Jean Paul Akayesu. (1998, September 2). International Criminal Tribunal for Rwanda, ICTR-96-4-T.

Prosecutor v. Kunarac et al. (2001, February 22). International Criminal Tribunal for the Former Yugoslavia, IT-96-23-T \& IT-96-23/1-T.

Prosecutor v. Mucic et al. (1998, November 16). International Criminal Tribunal for the Former Yugoslavia, IT-96-21-T. Prosecutor v. Musema. (2000, January 27). International Criminal Tribunal for Rwanda, ICTR-96-13-A.

Prosecutor v. Sainovic et al. (2009, February 26). International Criminal Tribunal for the Former Yugoslavia, IT-05-87-T.

Prosecutor v. Stakic. (2003, July 31). International Criminal Tribunal for the Former Yugoslavia, IT-97-24-T.

Prosecutor v. Tadic. (1997, May 7). International Criminal Tribunal for the Former Yugoslavia, IT-94-1-T.

Rittner, C., \& Roth, J. K. (Eds.). (2012). Rape: Weapon of war and genocide. St. Paul, MN: Paragon.

Rome Statute of the International Criminal Court. (1998, July 17). UN Doc. A/CONF. 183/9, 2187 U.N.T.S. 90.

Rules of procedure and evidence of the International Criminal Court. (2000, September 3-10). Doc ICC-ASP/1/3.

Schabas, W. A. (2006). The UN international criminal tribunals: The former Yugoslavia, Rwanda and Sierra Leone. Cambridge: Cambridge University Press.

Steains, C. (1999). Gender issues. In R. S. Lee (Ed.), The International Criminal Court: The making of the Rome Statute: Issues, negotiations and results (pp. 357-390). The Hague: Martinus Nijhoff.

Stiglmayer, A. (Ed.). (1994). Mass rape: The war against women in Bosnia-Herzegovina. Lincoln: University of Nebraska Press.

Tan, J. (2012). Sexual violence against children on the battlefield as a crime of using child soldiers: Square pegs in round holes and missed opportunities in Lubanga. Yearbook of International Humanitarian Law, 15, 117-151.

UNDP (1994). Human development report. New York: Oxford University Press.

Unger, R. M. (2015). The critical legal studies movement: Another time, a greater task. London: Verso Books.

Wood, S. K. (2004). Woman scorned for the least condemned war crime: Precedent and problems with prosecuting rape as a serious war crime in the International Criminal Tribunal for Rwanda. Columbia Journal of Gender and Law, 13, $274-327$.

Zelin, A. Y. (2014). The war between Isis and Al-Qaeda for supremacy of the global jihadist movement. Washington, DC: The Washington Institute for Near East Policy. Retrieved from http://www.washingtoninstitute.org/uploads/Documents/ pubs/ResearchNote_20_Zelin.pdf. 